\title{
Zafar, Watershed of Late Pre-Islamic Culture
}

\section{Introduction, State of the Research}

New research and the dissemination of this information to a scholarly as well as a broader public are revolutionising our understanding of the nature of late pre-Islamic Arabian society. In the introduction to our conference in February 2006, and in several new publications, Christian Robin has articulated that until recently the Himyarite Age has been little understood; its late pre-Islamic inhabitants being purportedly poor, isolated, illiterate, lacking a stable political system, and living as nomads in the desert. Recent research, however, contradicts this image. Since the 1970s, the tempo of research has accelerated and, with new textual and interpretational studies, one can speak of a general reinterpretation, especially regarding Himyar. Is one to explain the dramatic and far-reaching post-Himyarite religious, cultural, and economic developments of late $6^{\text {th }}$ early $7^{\text {th }}$ century Arabia as issuing full-grown from a historical vacuum? Do decisive cultural influences in Arabia at this time, then, derive from abroad, Himyar, and other indigenous formative bodies that played no real role or just a negative one? Today, no scholar would seriously consider Islam to have gained widespread acceptance solely with the diplomatic and military efforts of the prophet Muhammed in his generation. Other factors played a role, but which? ${ }^{1}$

Following comments on the state of research of late pre-Islamic Yemen, the reader will find a brief characterisation of highlights of archaeological fieldwork since 1998 in Zafar, capital of ancient Himyar. A short overview of the research on this late Old South Arabian (OSA) centre corresponds with the goals of our conference. Since the excavation reports on Zafar are still in press (Yule in press), new excavation results from the site are not commonly known. The main topics of the paper include the nature of the defences, the appearance of Zafar's cityscape, and its post-Himyarite history. The final section discusses briefly and from an archaeological point of view select aspects of late pre-Islamic Judaism in the highlands.

Few sites yield remains of the Himyarite period, and even fewer of these lie in the Himyarite heartland. Qaryat al-Faw of the Kinda (al-Ansary 1981) and Nagran (Zarins et al. 1983), key sites that have yielded significant relevant contexts and finds, lie to the north and outside of the Himyarite homeland per se. On the other hand, Zafar and Qani lie inside the general limits of the kingdom, the latter a spoil that fell to Himyar after its conquest of the kingdom of Hadramawt. The settlement of the lower town of Qani encompasses an area of $100 \times 250 \mathrm{~m}$. In addition, poised on an extinct volcano, the "fort of the crow" measures some 150 x $150 \mathrm{~m}$ (all in all $5 \mathrm{ha}$ ). In the $1^{\text {st }}$ century CE, Qani was a useful provisions station before continuing to sailt o the east or west. The excavator, A. Sedov, describes the presence of a lighthouse, storehouses, a "customs house" as well as a synagogue and a temple dedicated to a local deity (1998: 276). From the $2^{\text {nd }}$ to $5^{\text {th }}$ centuries, Qani's trade blossomed, judging by its imports from North Africa. In the $6^{\text {th }}$ and $7^{\text {th }}$ centuries, only the northwestern part of the town was inhabited (1998: 278). The finding of $80 \%$ of amphora sherds, which were the best-known imports discovered in the excavations at Ayla/Aqaba (southern

1The research below was conducted mainly during a period of munificent grants from the Fritz Thyssen Stiftung (20042005) and the DFG (2006). The General Organisation for Antiquities and Museums (GOAM) generously supported our annual campaigns in the Yemen. The present paper is an abbreviated version of the oral presentation. K. Galor contributed to the section on the Jewish presence in Zafar. We are submitting this paper prior to receiving the results of several radiocarbon samples that may alter the chronology in Zafar. We are grateful to Christian Robin for the invitation to deliver the paper and for the opportunity to discuss several of the points raised therein. Papers of the conference, Vieilles thèses et nouveaux documents le judaïsme en Arabie, des origines à l'aube de l'Islam, in print in Arabia revue de sabéologie. Diacritics not possible. 
Jordan), inform us that trade still flourished at this time. In the $7^{\text {th }}$ century, Qani had lost its importance and disappeared from historical view.

At the same time, Zafar, with its substantial ruins which are attributable mostly to the empire (c. 270-523) and late/post period (523-c. 560/570), fill in this historical picture. Excavation, find-recording and mapping at Zafar since 1998 have shed considerable light on the nature of the capital and material culture of the Himyar. It is paradoxical that the capital of a kingdom, which dominated directly and indirectly an enormous area encompassing most of pre-Islamic Arabia for some 250 years, until recently has remained a marginal topic in Arabian studies. This is all the more so since early Arab historians and other early medieval sources knew the Himyar better than the long-vanished kingdoms that preceded them. Most historians have short-circuited directly this connection of Arabian history, preferring to hark back to the age of the biblical and koranic Queen of Sheba and circumvent the "decadent" Himyar.

Excellent synthetic archaeological and historical studies (e.g. Vienna 1998) have revitalised the Himyarites. For those of us without extensive library resources, C. Robin's assembled relevant OSA texts in the present publication (2006) are helpful. Prior to this, numerous scattered publications discouraged all but the most determined to work, except superficially, in a few select libraries on the "late period." Aside from textual studies on the early highlands, two surveys took place - one broadly based in the area (Wilkinson et al. 1997) and a second centring on the agricultural history in and around Zafar (Barceló et al. 2000; 2003). The first covers from earliest to Himyarite times and the second covers essentially the latter period to the present day.

What is wrong with the usual characterisation of late pre-Islamic Yemen? Certain conservative colleagues denigrate this period at some length, contrasting, for example, the "good," linear, early art with the "bad," organic, later art. J. Schmidt refers to the "sinnentleerte Bastelei" (1997: 34-37) and S. Antonini to the "late" or "decadent $1^{\text {st }}-4^{\text {th }}$ century" (her quotation marks; 2001: 23). At first glance, this historical interpretation is appealing in light of the biological or Darwinian model of the bud, flower, and withering. But new finds contradict this conservative, if not old-fashioned, schematic method, which in reality functions predictably in few categories of ancient art and results in a self-fulfilling prophecy. Thereby, artefacts of mediocre quality can be assigned to the late period ignoring other dating attributes. We have here the pleasant opportunity to rehabilitate the Himyar and their culture. The denigration of Himyarite art resembles out of hand analogously the castigation of Late Antique art as decadent, discordant with its modern perception.

At the heart of matter lies the site of Zafar $\left(14^{\circ} 13^{\prime} \mathrm{N}\right.$; 44 ${ }^{\circ} 24^{\prime} \mathrm{E}, 125 \mathrm{~km}$ SSE of San'a and $230 \mathrm{~km}$ NNW of Aden), where creative cultural impulses are to be expected owing to its association with the royal house, its patronage and a surplus of wealth. Zafar is nestled in the chain of flattish craters formed by at least four irregularly shaped extinct volcanos. These rise above the surrounding rocky landscape to an altitude of some $2800 \mathrm{~m}$. The three main find areas of the ancient city include Zafar South (the present-day village), the Husn Raydan, and Raydan North (al-Gusr in the local dialect). Himyarite ruins are concentrated most heavily on the southern and western slopes of the Husn Raydan (Figs. 1-3), particularly on a broad slope known as al-Jahw. 


\section{Prima Facie Appearance of Himyarite Zafar}

Mapping operations illuminate the size, shape, and lay of Zafar. The main ruins form a cluster irregular in form inside a rectangle measuring some $800 \times 1000 \mathrm{~m}$ (E-W by N-S). One would expect the main palace to stand atop the Husn Raydan, the main local promontory. In 1998, a first test trench inside a 12 x $12 \mathrm{~m}$ structure (building z028) showed that further work in this profoundly disturbed area presented a dubious excavation opportunity for the investment of precious, limited resources of time and money. Some years later, Abdullah Salih al-Annabi from Zafar informed us that this was the site of a sub-recent settlement that was allegedly levelled by the "imam" many years, even centuries, ago because the villagers failed to pay their taxes. Given the vagueness of this story, the "imam" easily could have been a local governor of the first Turkish occupation (945-1045/1538-1636), who was known for his greed and harsh methods (Smith 2002: 273b). Conditions in the Yemen and elsewhere declined generally, including the population density. Poor site preservation on the Husn Raydan probably result from the aforementioned incident in addition to extensive subsequent stone robbing.

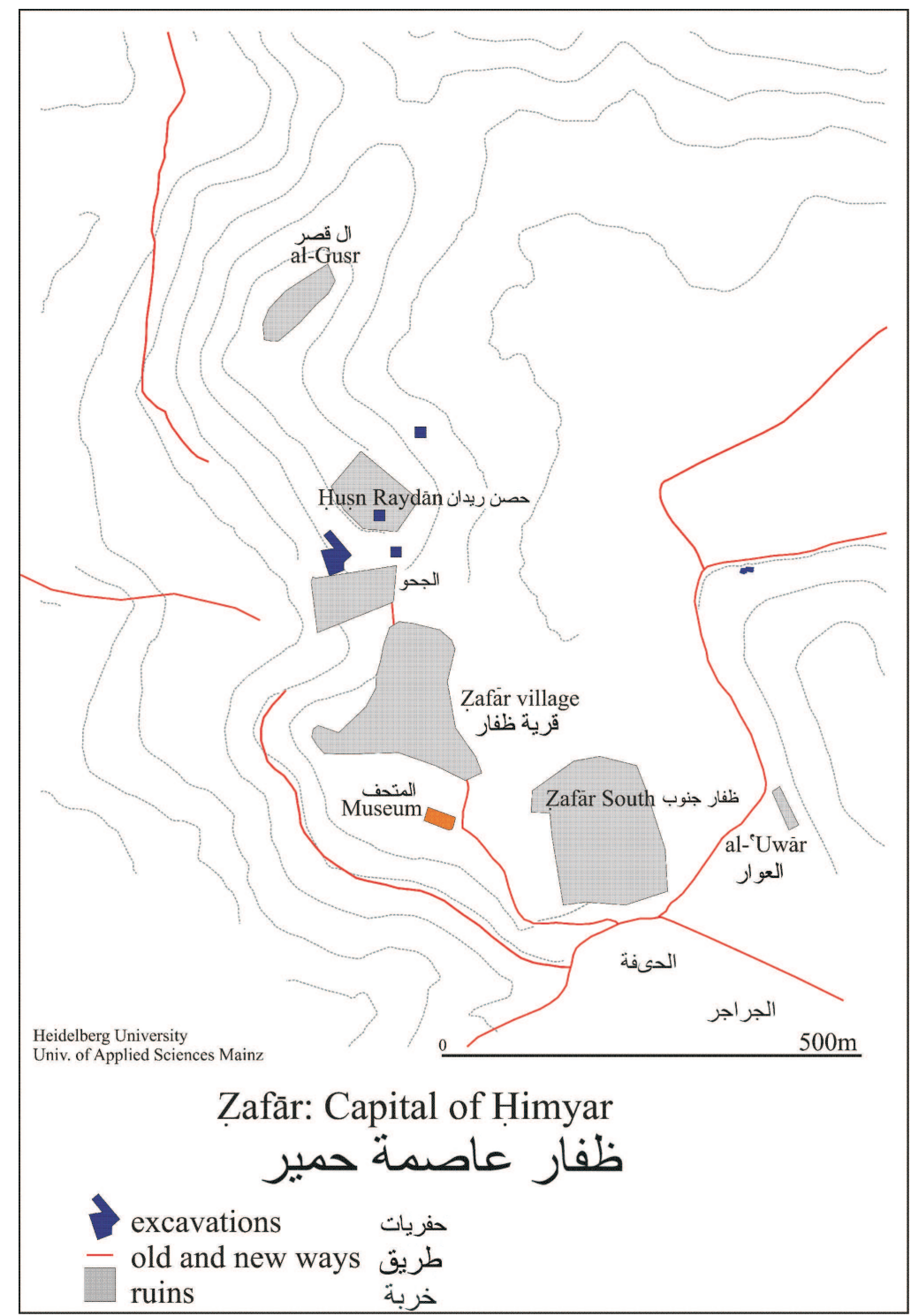

Fig. 1 Main ruin areas of Zafar. 


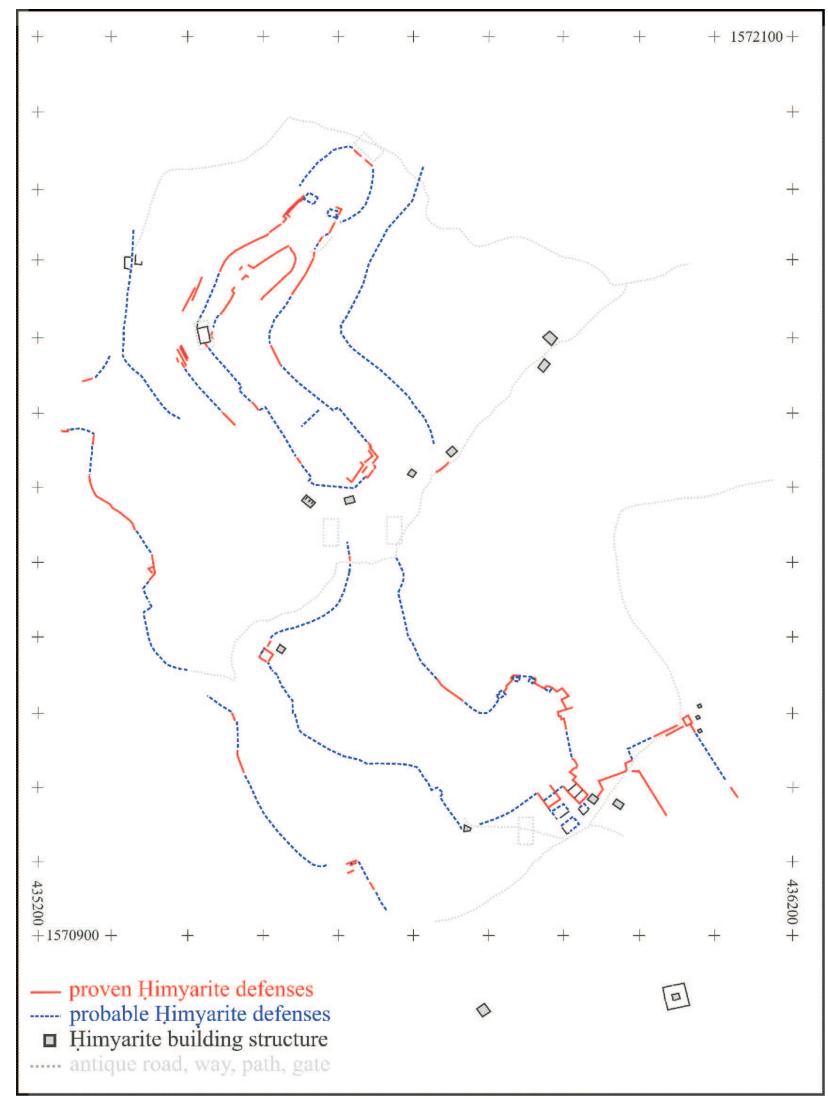

Fig. 2 Overview of the late antique period defences and roads/ways at Zafar.

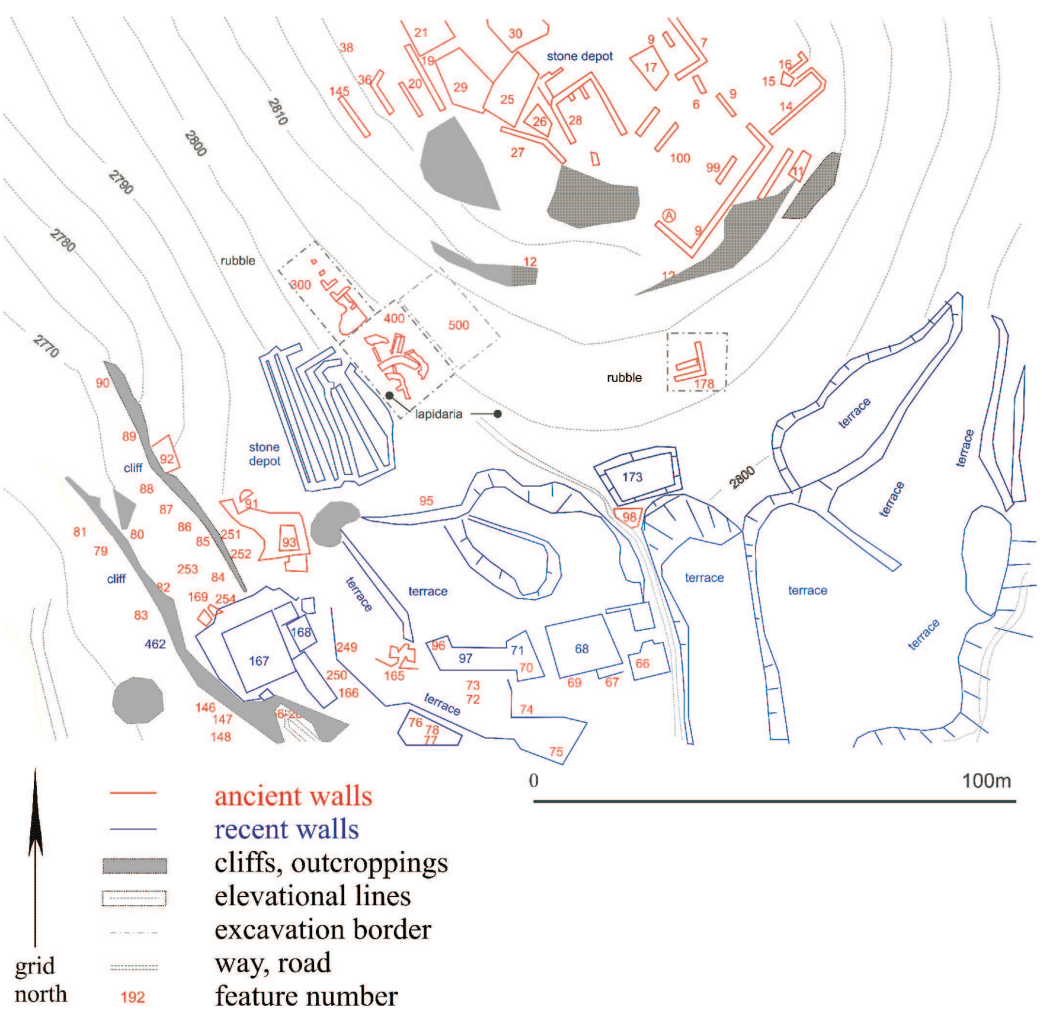

Fig. 3 Plan of Zafar/al-Jahw on the south-western flank of the Husn Raydan, condition: March 2006. 
Building ruins of two kinds occur at Zafar: those obviously Himyarite, and recent $(<70$ years old) stone houses and their ruins, that are built from Himyarite spolia. Himyarite masonry of the empire and late periods is characteristically made of stone; its timber-frame, wattle, and daub construction have not survived in Zafar. This manner of building is best known from other, slightly earlier sites, particularly Shabwa (cf. Breton 1991: 217 fig. 5). According to the size and purpose of the building, Himyarite building stone may vary in size and shape, but are regularly masoned. Within a given building structure they are relatively regular in size and overall appearance (Fig. 6). Terrace walls built in this technique belong to structures comparable to integral parts of the main Himyarite period fortifications. Clustered on the south-western edge of Zafar, a few foundation ruins form one of the few exceptions: Relatively isolated and irregular house plans show larger, somewhat coarser stones than the typical Himyarite houses.

In Zafar village the population began to regenerate around 1950 and hardly a building there predates this (Fig. 4). Reportedly some 300 years ago whatever inhabitants had survived built a small (interior size $3.7 \times 3.4 \mathrm{~m}$ ) cube mosque (feature no. z070) on top of what the local population considered to have been an ancient church (Fig. 5, see below). Unfortunately, however, we have little means to corroborate this dating. A photo taken of al-Jahw in 1970 (Müller 1979: cover) shows only the cube mosque, z070, and a simple stone shed over the large Himyarite tomb, z066. In past decades, inhabitants returned to Zafar from the outlying villages they had moved to when subsistence in Zafar had become untenable. Asking the locals when their houses were built elicits mostly the answer that this happened 40 to 50 years ago. However, the oldest "common house" in the centre of the village is said to be some 300 years old, perhaps contemporaneous with the old mosque. Most of the inhabitants have some idea of the age of their own house, but not a clear one about those of their neighbours. Thus, the area around the cube mosque, known as al-Jahw, was, in fact, built up mostly in the last 30 years, although young enthusiasts unwittingly claim a far higher date over 100 years old. During the construction on this spot, the villagers excavated Himyarite ruins, which are now used as storage facilities, particularly the tomb, z066 (Yule 2005: 25 Fig. 4). Nicely trimmed Himyarite building stones are a major source of building material, not only for houses in Zafar but also for the entire region as far away as Yarim, for example, for the main mosque there. Transport by means of camel and donkey was easier than actual stone-working. In this regard, it is difficult to enforce the preservation laws in Zafar, as is also the case in other countries. Several Himyarite contexts that we recorded are nearly or completely destroyed; many of our photos are already historic.

\section{Zafar/al-Jahw, Trench z300}

In the year 2000 (Yule et al. 2007), we tested two Himyarite buildings on the southern (building z178, Fig. 5) and eastern (z175) slopes of the Husn Raydan before deciding to partially investigate the extensive Himyarite cemetery site on the northern slope of Jabal al-Asabi (zc01). The eastern extension of building z175 has eroded away (Fig. 6). In 2002, excavation continued on the building foundation of z178, a structure measuring $12 \times 12 \mathrm{~m}$.

Subsequently in 2003, work (trench z300) commenced on the western slope of the Husn Raydan, part of which lies in al-Jahw. This and our subsequent excavation endeavour of 2004 and 2006, trench z400, were undertaken in the hope of finding remains of a monumental building in archaeologically more promising areas, to judge from the surface finds there, mostly relief fragments. Some $20 \mathrm{~m}$ east of structure $z 300$ (Fig. 7) the large and dated $5^{\text {th }}$ century building inscription of Shurahbiil Yafur (siglum: zm1) came to light around 1968 (UTM coordinates: $38 \mathrm{P}, \mathrm{e}^{4} 35541, \mathrm{n}^{15} 71533$ ), in which he recounts the renovation of the old 
Hargab palace. This important find gave impetus to look in the immediate vicinity, even if the find-spot of the inscription is secondary. Particularly inviting is the kings description of decorating the palace with new floral ornament in addition to the old ornament (Sima in press). The heavy overburden of stone debris and earth, which protected these two contiguous sites somewhat from the depredations of quarrying, alerted us to the possibility of better preservation here. The $20 \times 10 \mathrm{~m}$ trench z300 contains cubicles built of hewn stone blocks which are associated stratigraphically with a broad stone pavement. The masonry of the buildings is rustic. While the pavement slabs are somewhat irregular in shape, they fit so tightly together that one cannot put a knife blade between them. The identification as magazines is strengthened by the presence of large storage vessel sherds, however these may have fallen into z300 from the settlement above in the Husn Raydan. A provisional dating for z300 in the empire period is based on the quality of the masonry and the surrounding contexts.

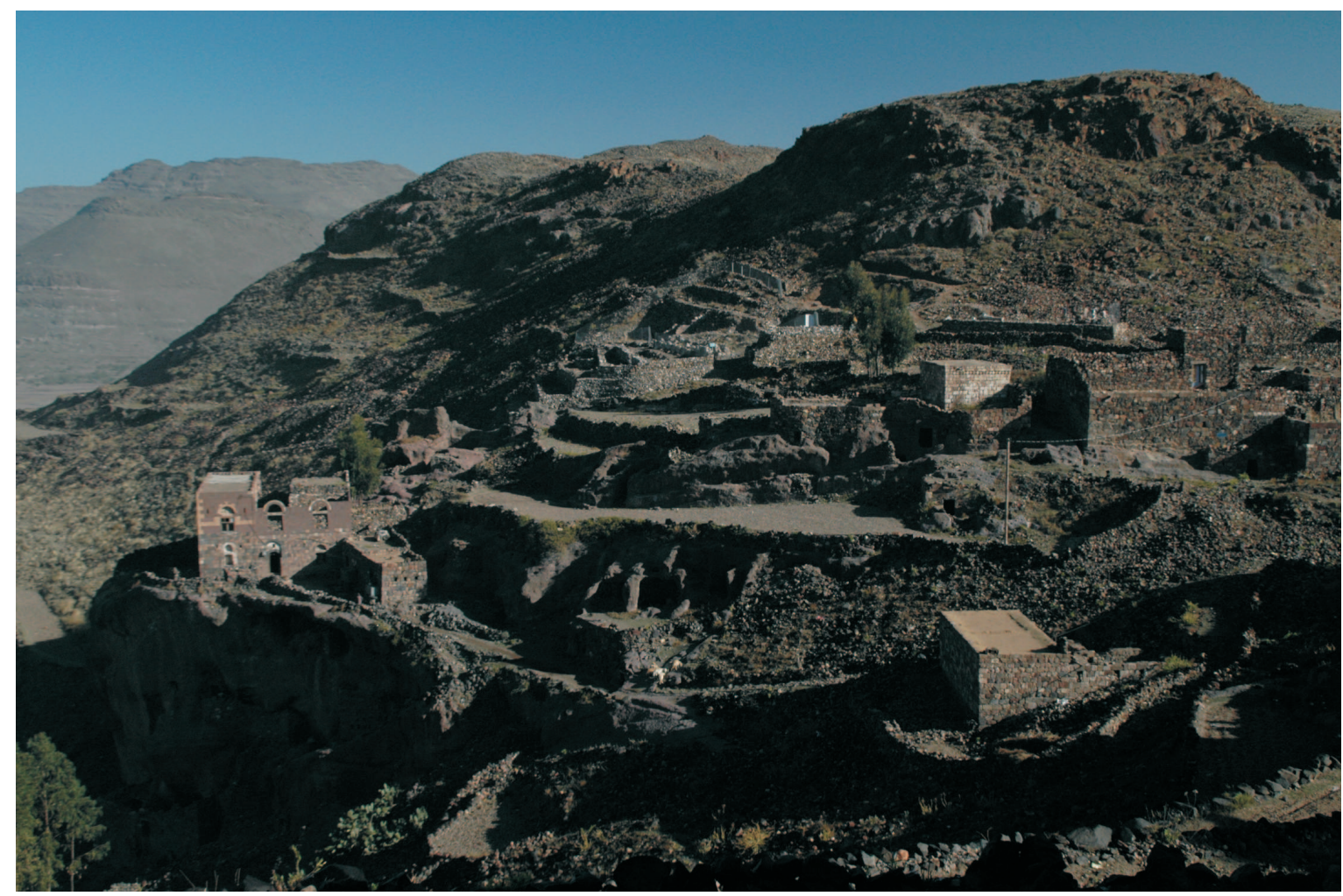

Fig. 5 Zafar/al-Jahw toward the north, 2005.

\section{Zafar/al-Jahw, Trench z400}

South of z300 and adjacent to it, at the time of writing this $20 \times 10 \mathrm{~m}$ trench also cut into the western-facing slope. In 2004 and 2005, excavations here revealed a building built of finely cut stone which was later intruded upon by a curving foundation wall fashioned out of roughly broken stone (Fig. 8-9). The date of this wall is presumably late pre-Islamic. The plan in Fig. 8 shows the northern and western walls of this stone building, both of which appear to have an entrance. Although the eastern and southern sides of the stone building are yet to be unearthed, the structure seems to be a court paved with thick stone slabs. At the southern end, a heavy slag deposit, which yielded radiocarbon samples, covers the Stone Building, postdating it. 
The find circumstances of this partly excavated court seemed at first to indicate a fiery destruction, but it is more likely that the large slag deposit derives from one or more kilns used after the Stone Building had fallen out of use. It contains a considerable amount of charcoal, reminiscent of kiln debris.

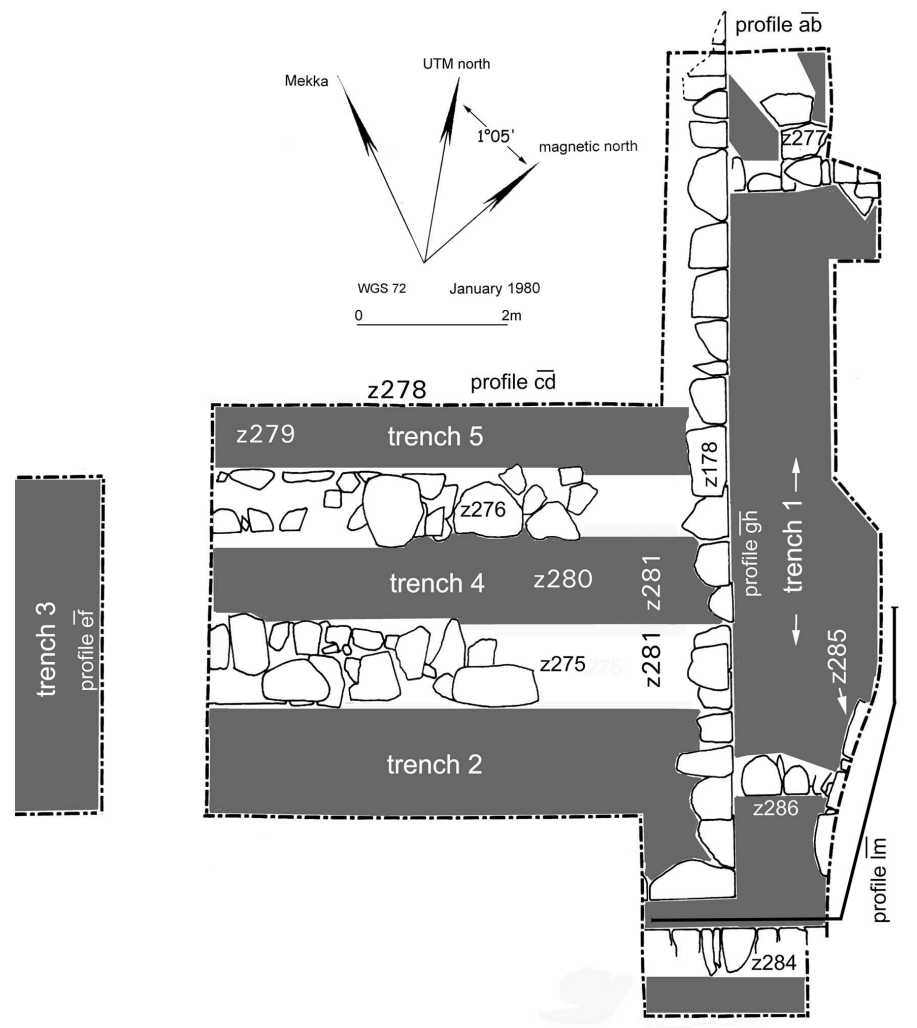

Fig. 5 Zafar/al-Jahw, sketch plan of the building foundation, z178.

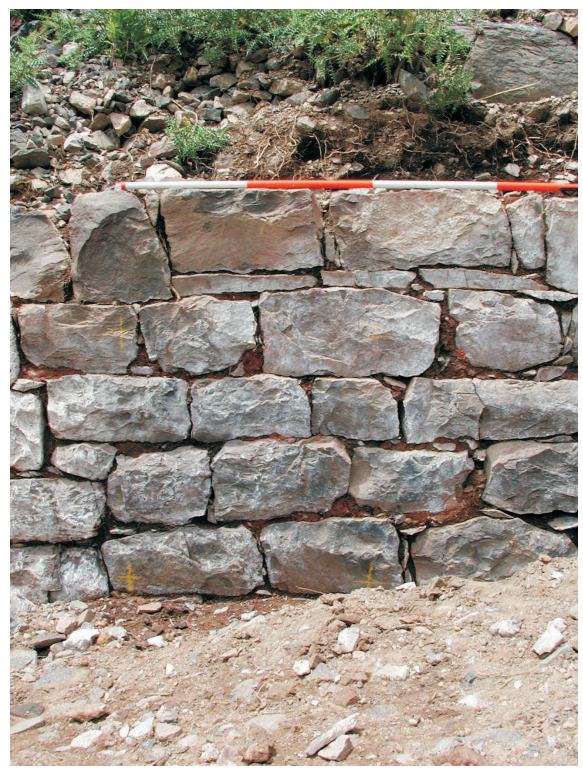

Fig. 6 Zafar/Husn Raydan, detail of fragmentary building z175 showing typical Himyarite domestic masonry. 
Regarding the date of the Stone Building, first, an inscription (in Robin 2006: 1.A.b. 1= Gorge du Haut-Bura' 2) mentions the Hargab palace in Zafar around (351 CE). Given the proximity of the above-mentioned re-building inscription of Shurahbiil Yafur (the month dh-' $^{\mathrm{n}} 572 \mathrm{Him} /$ September $457 \mathrm{CE}$ ) describing the renovation and redecoration of the palace (Sima in press), an identification with this building seemed possible, now it is impossible Moreover, carbon 14 dating provides a terminus post quem for the Stone Building in trench z400 (in greater detail, Yule et al. in press). Even if some of the carbon samples lay on the floor, they need not and seem not to be contemporary with it. The available determinations cluster in the $4^{\text {th }}$ century. Further assays from favourably located find-spots on and under the floor may shed more penetrating light on the chronology of this attractive structure.

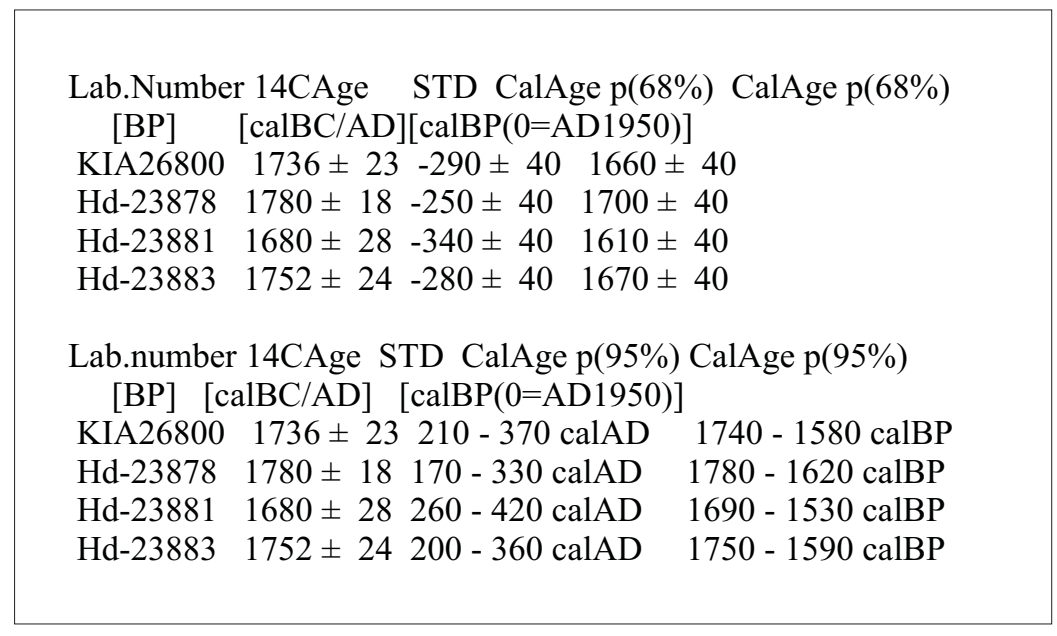

Calibrated AMS and ${ }^{1} \mathrm{C}$ determinations from z400.

A third means of dating the Stone Building is the marginally drafted pecked masonry which decorate it (Fig. 10). This decoration of G. W. Van Beeks Type 6 (1958: 287295, esp. 291b and 295b)smoothed face; blocks and courses simulated by incised lines defining borders and pecked areas on each panel; sparse and oblique peckingis known, according to Van Beek, from a period between the first century CE and the "last Pre-Islamic period," presumably $630 \mathrm{CE}$. Few comparisons, dated or undated, are available for this period, but similarly decorated masonry occurred in the 1999-2000 Italian excavations at Tamna in contexts dating from $c$. the $3^{\text {rd }}$ century BCE to the mid $1^{\text {st }}$ century CE (personal communication, $\mathrm{S}$. Antonini, 19 May 2006). Further examples have come to light at Baraqish that date from the $4^{\text {th }}$ to $1^{\text {st }}$ centuries BCE. Several other such decorated stones exist at Huqqa, al-Sawda and al-Bayda, not all of which are published (Rathjens and v. Wissmann 1932: 49 Fig. 15-16, cf. also Radt 1973: Taf. 11,34a: "wohl Marib"). Parallels for this kind of stone-working are found in the later phases of the Baran temple in Marib (personal communication B. Vogt). These finds somewhat widen Van Beek's dating for his Type 6, as they derive from contexts which are not closely datable. Based on the fine quality and workmanship of the masonry, the excavator suggests an origin for the Stone Building in trench z400 in the $1^{\text {st }}$ or $2^{\text {nd }}$ century CE. Since little is currently known about the workmanship of later periods or of the post-empire, this conclusion may need to be revised in the future. 


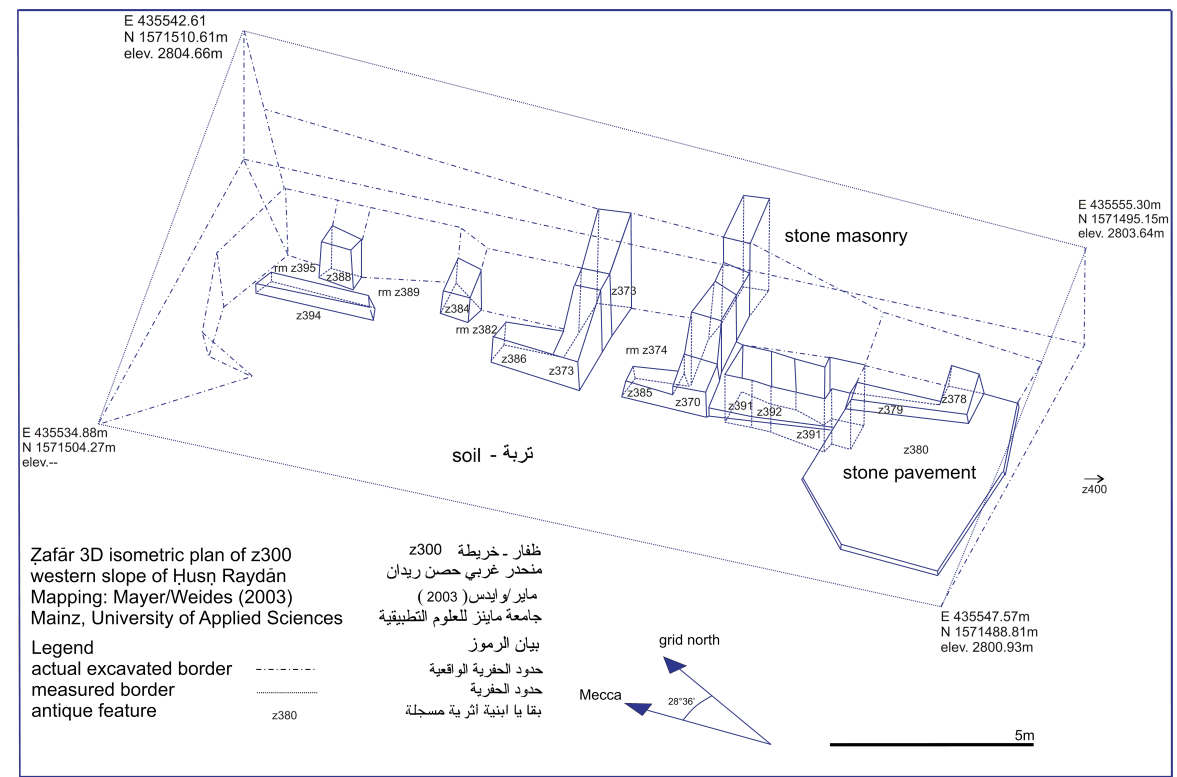

Fig. 7 Zafar/al-Jahw, isometric view of building in trench z300.

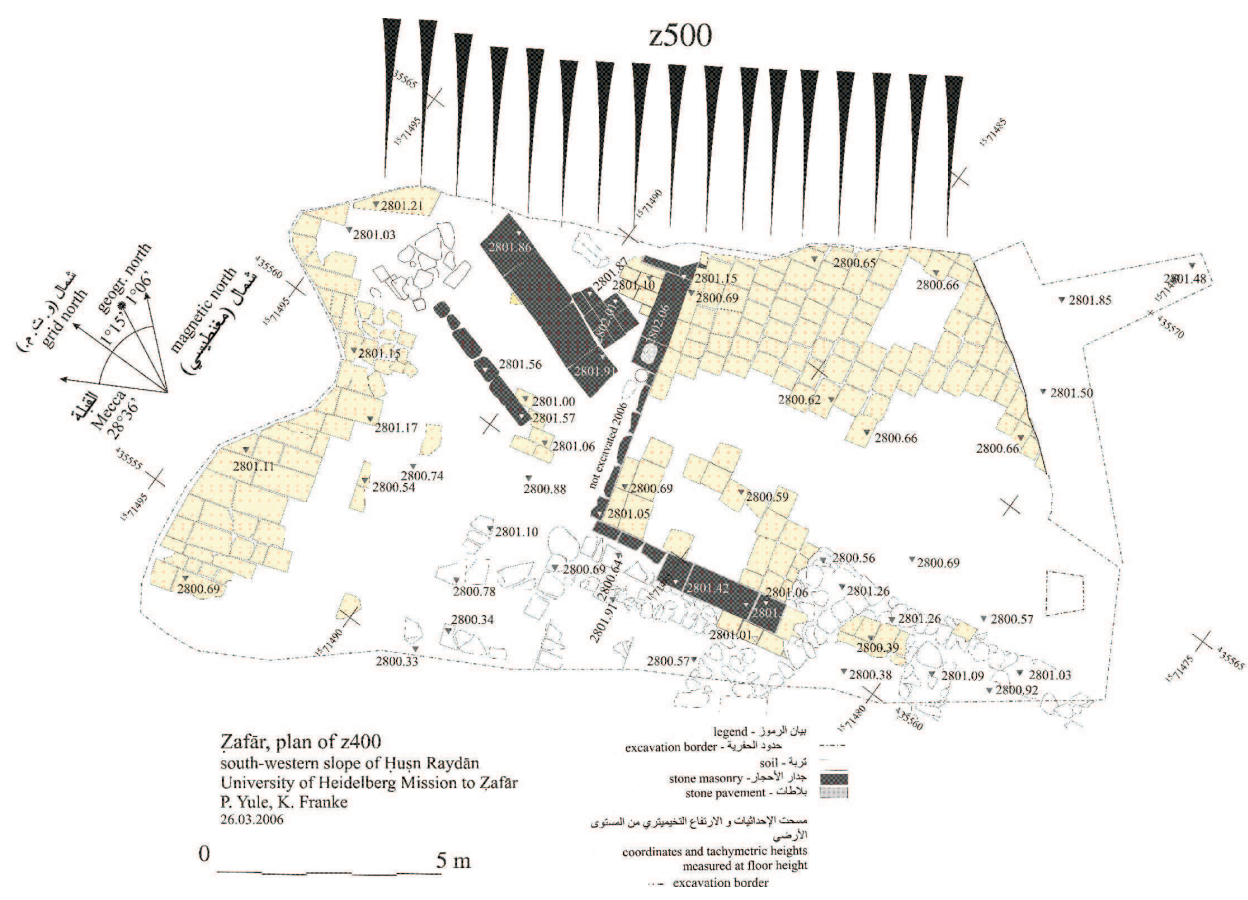

Fig. 8 Zafar/al-Jahw, plan of trench z400 with stone building and "steps". 


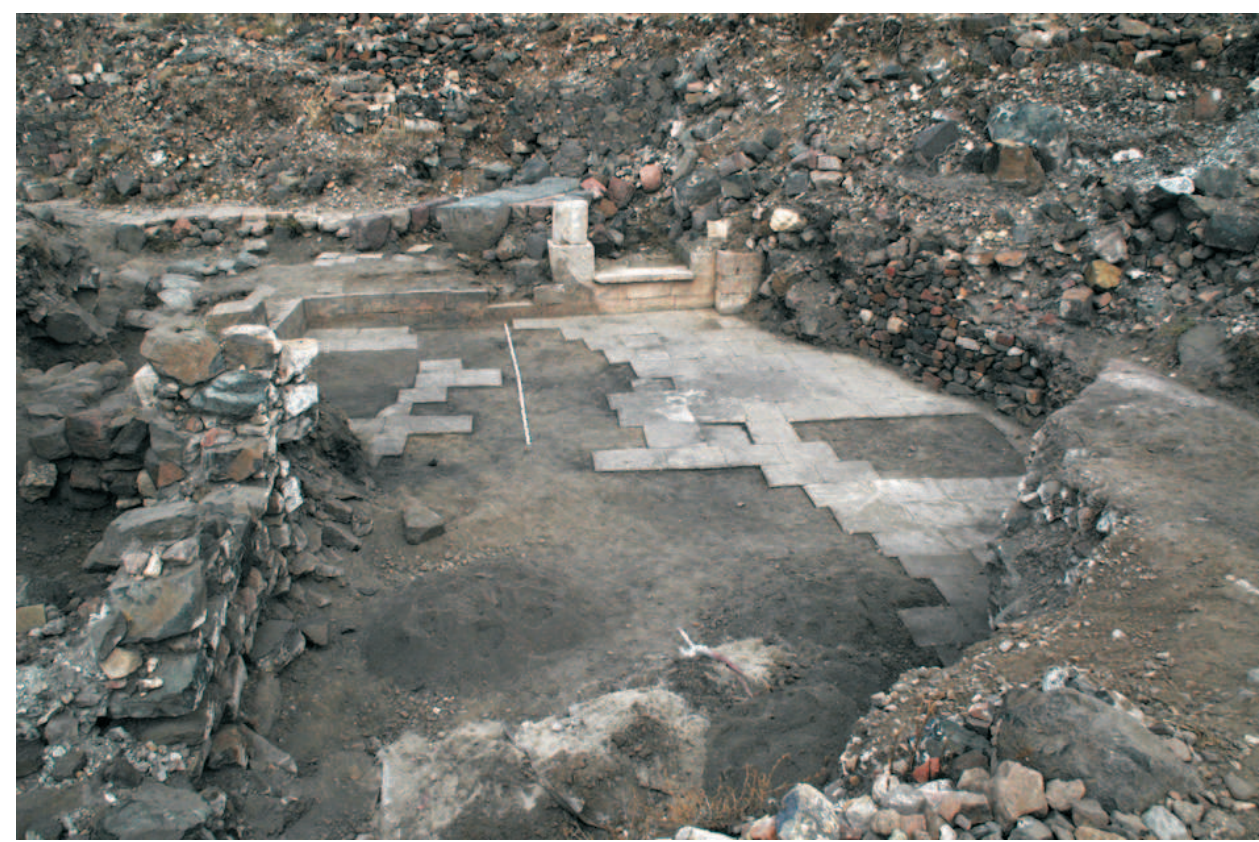

Fig. 9 Zafar/al-Jahw, stone building during excavation, 2006, toward the north-east..

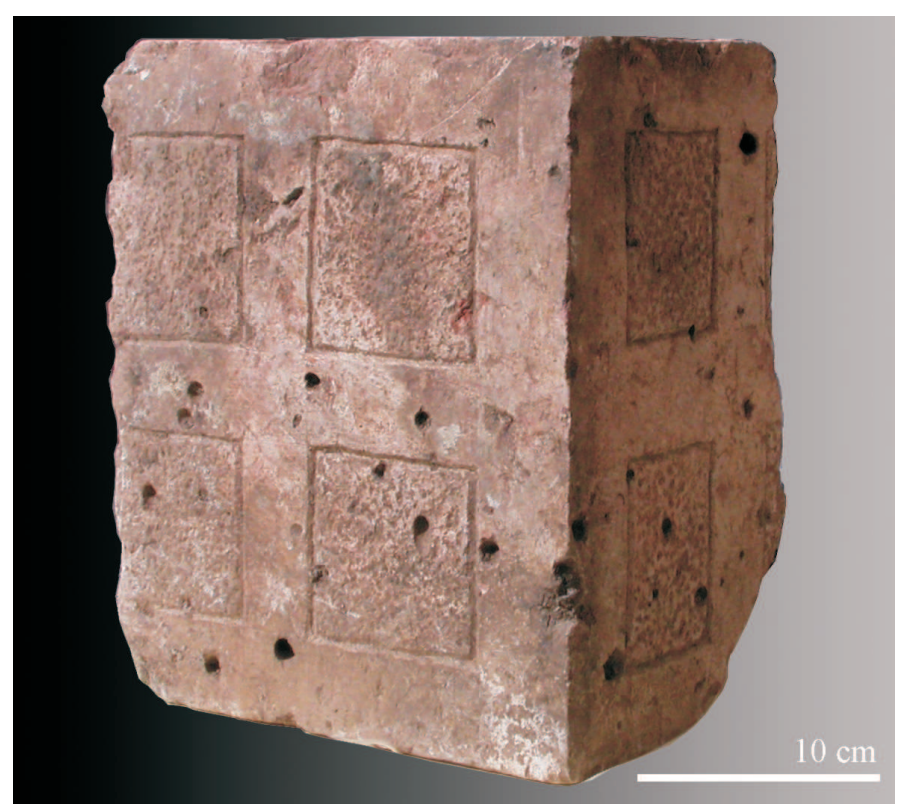

Fig. 10 Marginally drafted pecked masonry from entrance z415 of stone building; 28 x 29 x $23.5 \mathrm{~cm}$.

\section{Zafars Himyarite Defences}

Although less than $1 \%$ of the city walls still stand (ascertained by means of survey and satellite imagery), the outermost city defences are estimated to have originally measured some $4.5 \mathrm{~km}$ in circumference. The defences by no means consist solely of masoned walls, but also of cliffs sheared off together with them, trenches, and the natural topography. The inner defensive ring is easier to identify than the fragmentary outer one (Fig. 2). What remains of the fortifications eludes precise dating. Heavy, well-masoned and patinated cut stone walls are generally considered to be Himyarite; this means of dating still has little confirmation 


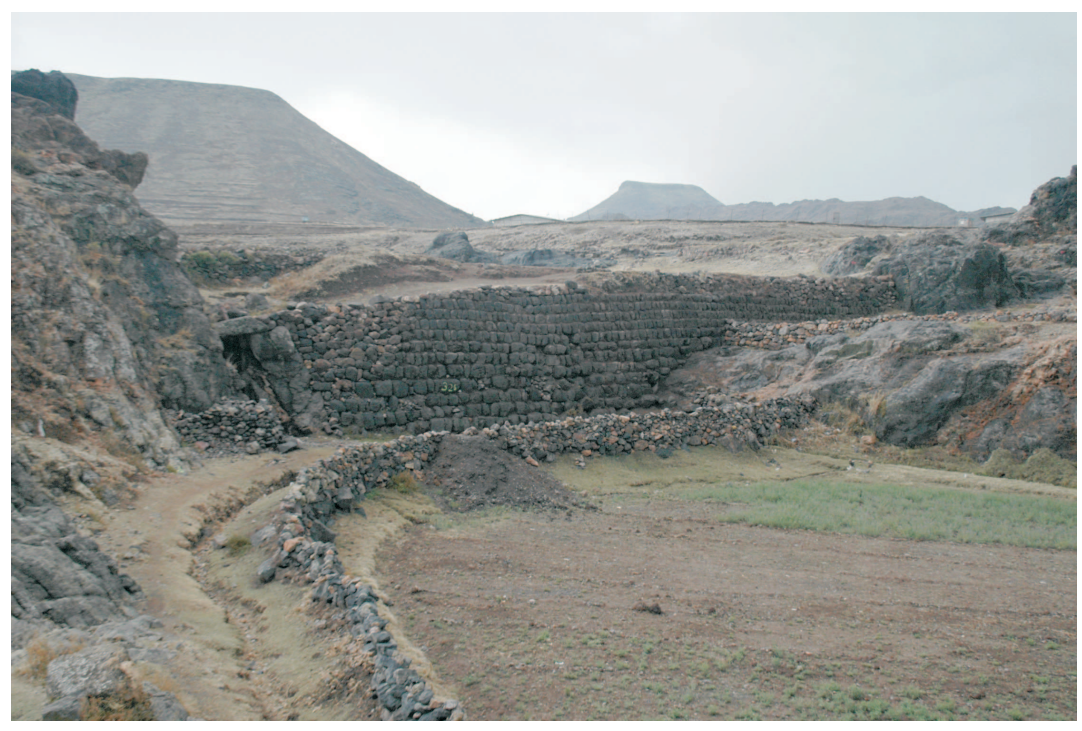

Fig. 11 Zafar/al-Shugag sadd z326 toward the north-east. An ancient well is located on the left (north) side of the dam.

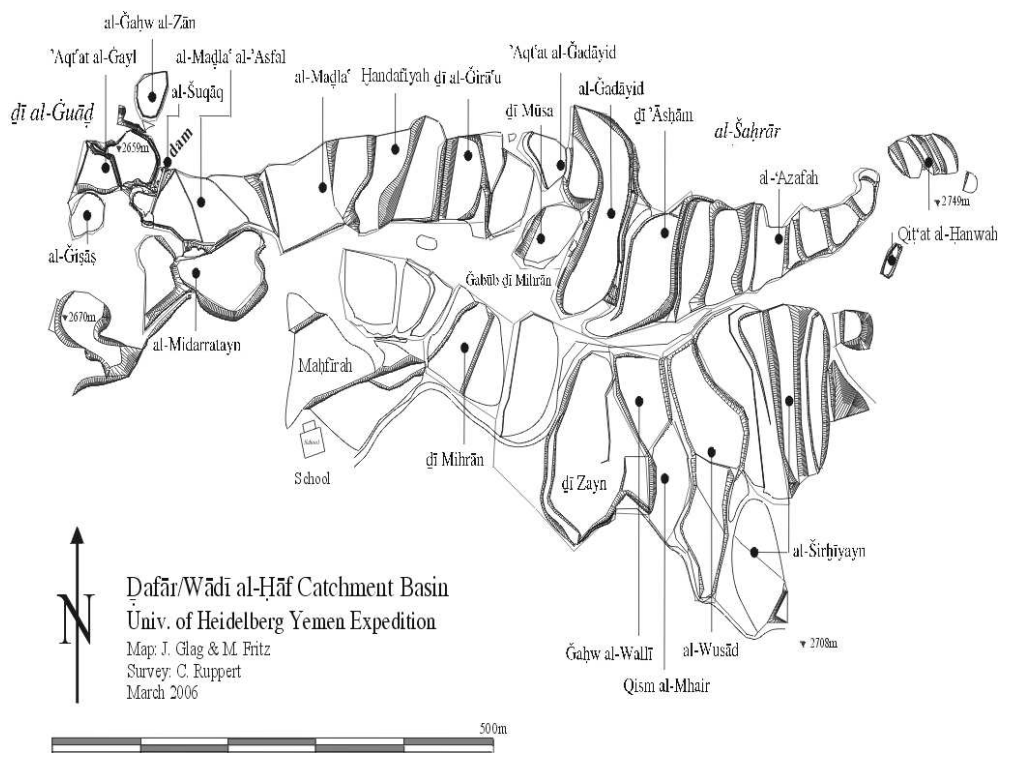

Fig. 12 Zafar/Wadi al-Haf, showing the field names.

by means of absolute dates. It is impossible to draw more than a sketchy plan of the entry zone, even if its rough outline can be made out (Fig. 2). Thus we do not yet know how wide and high the main walls were, and we must estimate the intervals between towers, few of which have survived. Moreover, in the post-Himyarite period, after the fortifications had fallen out of use, some were found re-used in the construction of the sadd (dam/retaining wall) in al-Uwar (Yule et al. 2007).

Some 30 years ago, a building inscription came to light in Zafar/al-Uwar (zm2263+2262+ $2264 / 2$ ), presumably originally set into the city wall or gate it describes. A. Sima determined that part of them may have been strengthened by means of a defensive trench (2002). Intra muros, the Husn Raydan had its own defensive walls, the main ones of which are still 
visible. The main preserved defences lie south of Zafar South, in al-Jabubat Laqiyah and alHayfah. Certain anchoring points exist for their dating: The aforementioned building inscriptions from al-Hayfah record a rebuilding of the city wall in 347 Himyar/232 CE (assuming a beginning for the Himyarite calendar in 110 BCE). Barceló refers to this "epigraphic tablet" as dating to the mid fourth century CE (2003: 141); this dating for the defences can thus be corrected here.

\section{The Cityscape}

The core of Himyarite Zafar spreads over the southern and western slopes and the summit of the Husn Raydan, the fortified al-Gusr, and the present-day village. The ancient city extends eastward and southward outside the city walls. To the east of the Husn Raydan, heavy accumulations of stone debris are visible around the present-day fields where houses once stood. But to the south of Qaryat Zafar, a Himyarite domestic quarter lies intact under a debris layer along the road to neighbouring Bait al-Ashwal, especially in al-Hayfah and al-Jirajir. With a few exceptions, little evidence exists for settlement to the west and north of alGusr, and in all likelihood there was little there from the outset. There is no lack of evidence for ancient building on top of al-Gusr, where the foundation walls of an over $100 \mathrm{~m}$ long structure came to light. On top of the Husn Raydan building remains are scrappy and difficult to date owing to a lack of surface pottery. Numerous ruins in and around the present -day village are of clear Himyarite date, the most notable concentration lying just to the south intra muros on Jabubat al-Laqiyah. In February 2004, while widening the access to the village, Zafar's main ancient paved entrance (z190) in the south was extirpated. A little further into al-Hayfah, bulldozing in 2000 and 2005 all but obliterated the major entrance to the city.

At present, five main city gates (Fig. 2) can be localised by means of their associated roads/ ways but more probably existed, judging from the size of the city and al-Hamdani's description of nine gates. None of them are well-preserved. From the heavily preserved remains, it may be surmised that the main gate lies at the southern end of the present-day village. At the opposite end, to the north, lies a second gate, at the eastern extremity of Raydan North. At mid latitude to the east and west, the lay of the ruins and present-day roads/ways conform to the ancient topography and suggest here flanking entrances. Certainly there were gates in the middle part of the irregularly shaped $1200 \mathrm{~m}$-long north-south-oriented settlement. The gate on the western side lies adjacent to bab suq al-layl, (gate of the market of the night), which hints at the presence of a gate where one is expected for archaeological reasons. A path leads past large numbers of rock-cut tombs directly to the main part of the core area, al-Jahw. A fifth gate, still visible, lies in the saddle between the Husn Raydan and al-Gusr and is visibly accessible to the west, but presumably also to the east judging from the lay of the ruins and other characteristic traits. Using the area of the site as a basis for calculation, J. Schiettecatte, in a fine study on the development of the "ville" (his quotations marks), calculates a population between 50,600 and 75,900 for Zafar (2004: 141, Table 2, 10 to 15 inhabitants per structure), making it the most populous city in South Arabia. But given the uneven settlement density of this site (the mapped area is $110 \mathrm{ha}$ ), the number of dwellings and population would be less than this.

\section{Continuity of Post-Himyarite Settlement}

Zafar is both a rewarding and frustrating archaeological site for the chronologist. On the one hand, stone relief fragments are numerous in our trenches at the site, by volume five times more than the pottery sherds. Particularly the reliefs raise hopes of finding the intact datable building structures which were once decorated by their well-to-do patrons. 
The chronologies for the reliefs and pottery of the empire and late periods are still generally undeveloped (cf. Wilkinson, Edens and Gibson 1997: 128-129, fig. 19) and their pottery sequence rests almost entirely on unstratified surface contexts. Numerous hitherto unknown and attractive sculptures often derive unfortunately from debris; further excavation is necessary in order to locate more useful structural/historical contexts. A few, however, do reveal the age or historical context of the find and help to date the considerable holdings of the site museum. While not emerging from controlled excavations, reliefs from the site museum, with but few exceptions, come from the immediate area, which gives an impression of the art of the highlands. The quantity and artistic quality of the new artefacts in the site museum places heavy obligations on the expedition to make some historical/chronological sense of this rich material.

Aside from the Stone Building in trench $\mathrm{z} 400$, which is the most intact such building on site (Fig. 8-9), few finds and contexts in Zafar date to the early Himyarite period. In the collection of the site museum, however, one musnad inscription written boustrophedon is clearly early (Sima in press). Several column capitals in Himyarite contexts also appear to be spolia looted from other early sites. On the other hand, the empire and late periods are known from the pottery and finds, and are still under study (see below). The first radiocarbon assays already give fixed points for important pieces from the excavation and from the museum collection.

The evidence for post-Himyarite habitation at Zafar, at the late end of the timeline, is contradictory. M. Barceló indicates a continuity in the settlement from the $2^{\text {nd }}$ century CE to the present day by virtue of the occurrence of archaic place-names for dams and their associated terrace fields in al-Hamdani's (AH 334/CE 945) al-Iklil, many of which he reportedly has identified (Barceló et al. 2000; 2003: 140-141). He bases his proposed settlement continuity on long-lived place-names and certain finds. Paradoxically however, our work has not yet yielded much evidence from pottery and other finds even possibly datable to the Islamic Age or any part of it.

Inscriptions shed some light on the late history of Zafar. In 658 Himyar/548 CE, the Axumite ruler Abraha wrote on his large 'Res gestae' stele in Marib that a year earlier he suppressed, by means of thousands of troops what sounds like a widespread insurrection judging from the number of opposing tribes he names. Whether Abraha chose to move the capital as a result of the stamping out of the ruler Sumuyafa Ashwa's revolt in 535 or because of the insurrection of 547 is unclear. Nor is there substantial evidence for a post-Himyarite settlement at Zafar. But a hint of the developments comes from Abraha's building of the cathedral in Sanaa c. 560/565 CE, which was Zafar's swan song as a capital. Abraha's longknown intention to make Sana'a a pilgrimage centre would have been a real step forward for the country. In any case, with few exceptions, the only firm evidence for the post-560/ $565 \mathrm{CE}$ habitation of Zafar is found in the descriptions of al-Hamdani.

One site at Zafar which may shed light on the post-Himyarite period is the aforementioned rolling settlement ruin mainly in al-Jirajir (extra muros to the south), which is transected by the road to Bait al-Ashwal to the south. This settlement seems less disturbed archaeologically than Zafar's centre. The pottery finds there appear to be of Himyarite date but require further study. 


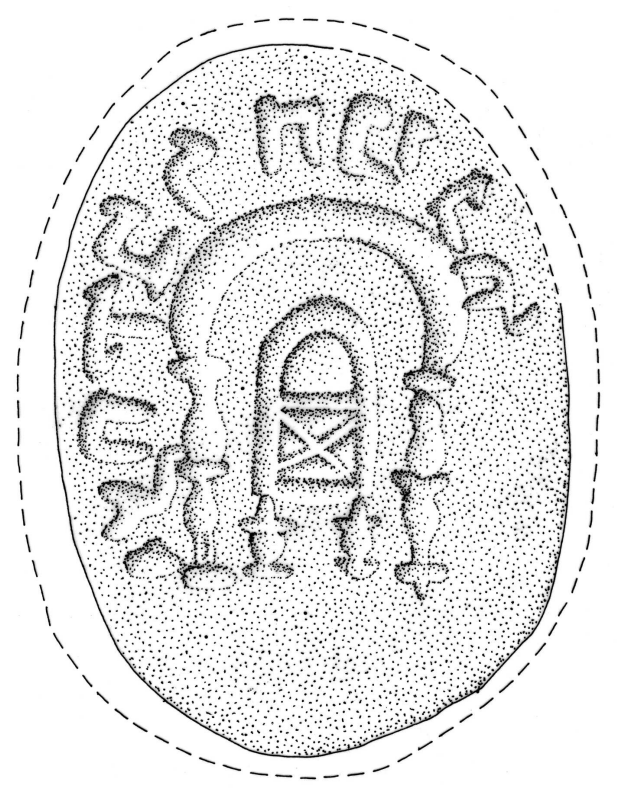

Fig. 13 Seal ring of Yishaq bar Hanina, from Zafar/al-Asabi/al-Salm; longest dimension c. $1.2 \mathrm{~cm}$.

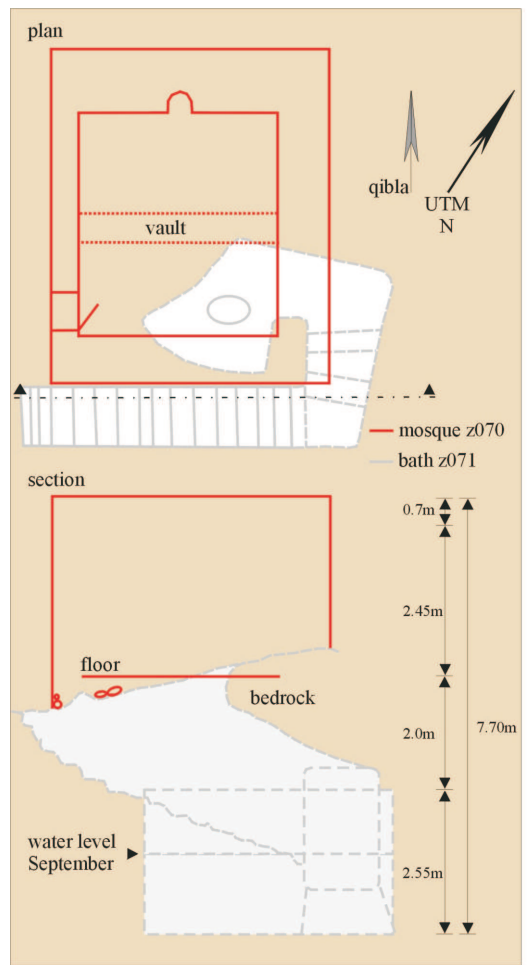

Fig. 15 Above: plan; below: $x$-ray view of the cubical mosque (z070) and rock-cut chamber (z071).

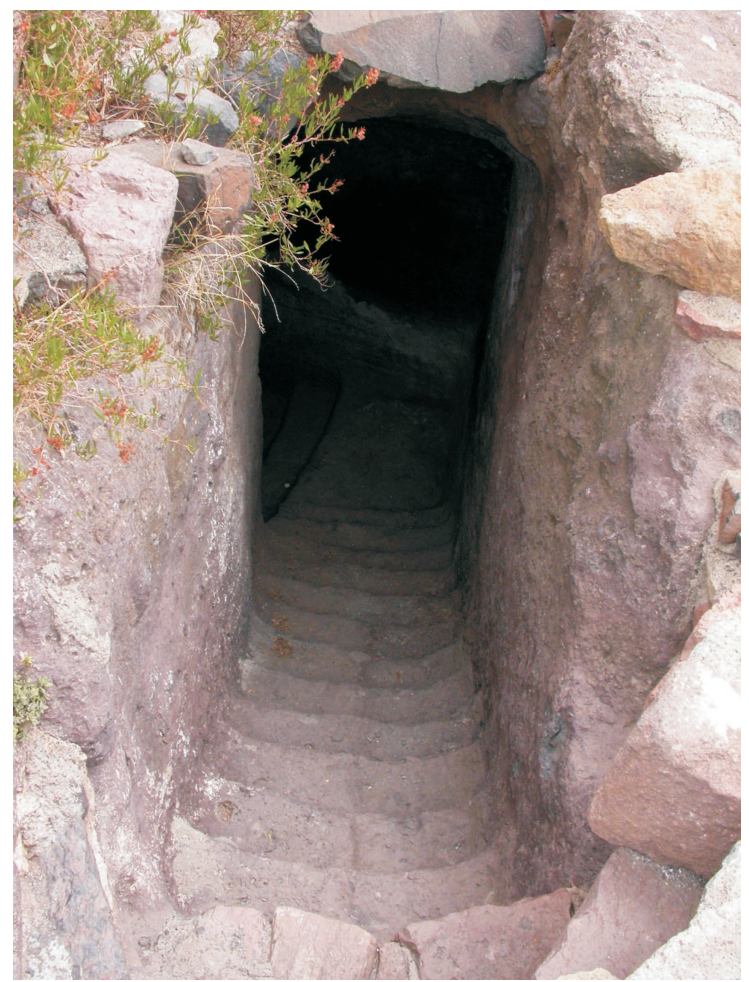

Fig. 14 Zafar/al-Jahw, stepped entrance to the rockcut chamber (z071), view to the north-east.

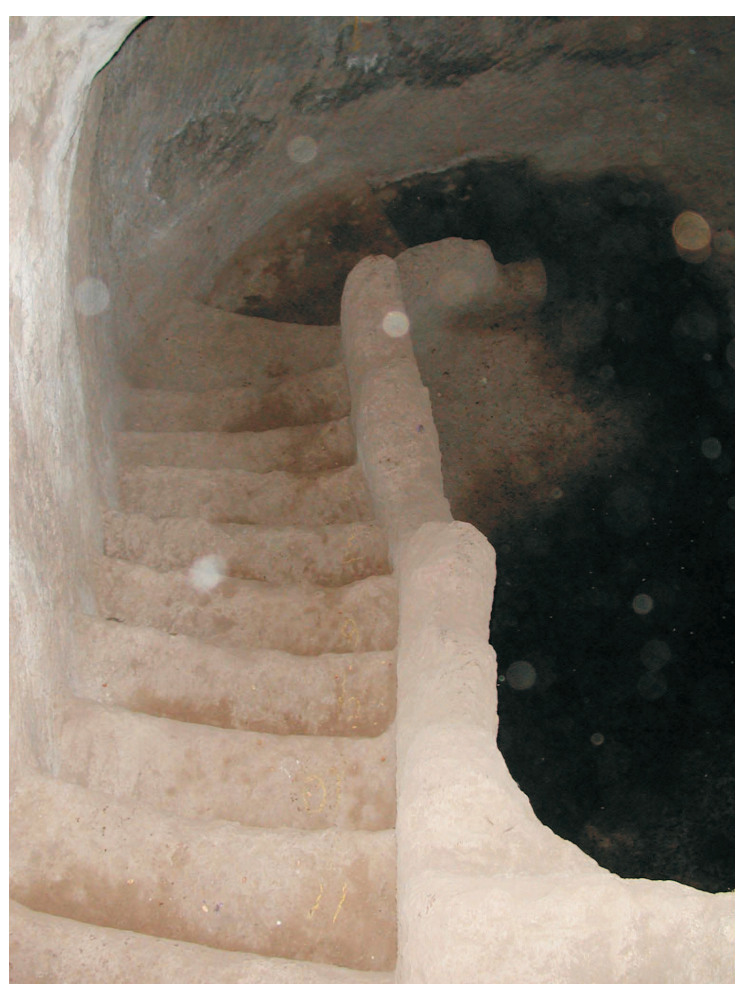

Fig. 16 Zafar/al-Jahw, view looking down into the cistern z096 to the south-west 
In 2006, our research gained momentum in an effort to illuminate fossil place-names around Zafar which are possibly preserved in the present-day archaic local dialect (Behnstedt 2002). As yet, we have identified but a few surviving examples from Himyarite times to the present day (e.g. Jabal Hadaman). We documented a Himyarite sadd/jirab combination (dam and field) in Zafar/al-Shugag, which is mentioned in al-Iklil. This served as a training ground for our multi-disciplinary team of two survey engineers, an archaeologist, and a semiticist. The over 1500 years old sadd corresponds to what is considered to be typical Himyarite masonry (Fig. 11): heavy, regularly cut and laid stones which have become patinated black over the centuries. However, the chronology for the entire associated complex of dams and fields is problematic as a result of multiple proven re-buildings of the asdad or dams in the wadi to the present day (Yule et al. in press 1). Elderly villagers tell us that certain walls, which at first glance we took to be ancient, in fact are new and are built re-using ancient blocks. Surface finds, such as potsherds in the drainage basin, are indeed rare and of no use in dating. Although several field names (Fig. 12) are archaic (e.g. dhi al-Jadhub), such forms may carry over into the mainstream of Classical Arabic, which is traditionally considered to have begun $c .500 \mathrm{CE}$ and are not limitable in date. 3

The main problem for the determination of habitation survival at Zafar is that in the absence of definable archaeological contexts and/or carbon 14 determinations from the early Islamic age after several seasons of excavation only a single context (a fortification/terrace wall in al-Uwar) might conceivably closely follow the fall of Himyar (Yule et al. in press). 4 Thus, if the fields around Zafar were in continuous use over the centuries, why is there no evidence there for settlement in the final death throes of the already defunct Himyarite confederacy in the mid late $6^{\text {th }}$ century? The Book of the Himyarites cites one passage in which dhu Nuwas departs from his "capital" in Sanaa toward Najran. Other evidence suggests the move of the Himyarite capital from Zafar to Sanaa around $560 \mathrm{CE}$, which jibes with Abraha's building of the cathedral there. Could Zafar simply have ceased to exist? If so, one can hardly expect royal patronage and development of the site (Lafitte 2003: 79).

Despite al-Hamdanis early mention of several asdad in the vicinity of Zafar, and the survival of place-names to the present day, this source in itself sheds little light on the continuity of post-Himyar settlement. Although, the general impression one gets from the different sites is a drop in the population density of the highlands after the fall of the Himyar, how drastic was it really? A small population would suffice to preserve the place-names to the present day. Surface survey reveals little evidence in this regard. Future work centres on locating intact contexts of the empire and late phases.

\section{Jewish Presence in Zafar: An Archaeological Perspective}

C. Robins recent study (2003) on Jewish presence in Zafar enjoins us to systematically evaluate the existing epigraphic and literary evidence. Thus, around the year 380, monotheism in general comes strongly to the fore. Under Tharan Yuhanim (c. 324-c. 375), the Jewish community in the Yemen is large and influential (2003: 154), however the events leading up to this blossoming remain obscure. While the excavations and stray finds at Zafar shed some light on this matter, overtly Jewish attributes are rare in the archaeological

3 Certain Arabic inscriptions are centuries older than this, e.g. from Qaryat al-Faw, al-Ansary 1981: 146, Pl. 1 $=63$ (from the tomb of 'Ajl bin Haf'am).

4 A group of heavy foundations of unusual form on the south-western slope of the Zafar village is not datable and is a potential candidate for medieval settlement. 
record. Moreover, several possible indicators of Jewish presence can be cited, although their validity is often uncertain and questionable. The tombs and graves excavated on Jabal al-Asabi (Yule et al. in press 1) belong partly to the late period but offer no firm evidence regarding the beliefs of the interred. Nor are burial and grave customs (e.g. grave/tomb forms) comparable with those of well-documented old Jewish populations. For example, no explicit Jewish symbols have as yet been identified. Yet, inscriptions such as that of Yehudah Yakkaf (siglum: Bait al-Ashwal 1) from the first half of the $5^{\text {th }}$ century possess sufficient information for us to learn of his confessioneven without the Hebrew inscription written inside the monogram. But when did the first Jews arrive in the area, and which artefacts were produced for Jews or reflect Jewish content?

In 2002, Ali Abdullah al-Zafari from Zafar showed P. Yule a ring that was purportedly "found" a few years earlier in the same place as our excavation at al-Salm, on the northern face of Jabal al-Asabi. The intaglio is an opaque red carnelian, flat in section and ovoid en face, which is dominated by a Torah Shrine. The name Yishaq bar Hanina appears engraved in mirror image, and although the personal name Yishaq appears in biblical Hebrew, Hanina does not. In his publication of the ring device, G. W. Nebe notes that the name was known between 330 BCE and 200 CE (Ilan 2002: 103-105) but also later, in the synagogue inscription at el-Hammeh (Beyer 1984: 384 (just before $438 \mathrm{CE}$ ). In the course of our meeting in Jerusalem, Yosef Tobi pointed out that numerous other late occurrences for the name are known, thus lowering its lower terminus. Different, but not very unusual, is that the Jewish-Aramaic owner is called "son of," not ben but rather the Aramaic bar. To judge from the script, names, and iconography, a date from the $2^{\text {nd }}$ century CE onward seems plausible. The kind of stone, its reverse inscription, and the motif all bespeak a seal.5 This ring is undoubtedly ancient and provides evidence potentially for the earliest Jewish settlers in the area. Even though the seal ring and its "Jewish" character represent a relatively unique find at this juncture, one should keep in mind the occurrence of similar finds in other areas of the Mediterranean littoral, where Jewish presence is attested in the Roman and Byzantine periods. The majority of inscriptions uncovered in "Jewish contexts" indicate a strong assimilation to the local cultures both in terms of the languages used and the names adopted. This is the case not only for inscriptions found in regions where Jews constituted a minority, such as North Africa or Italy, but also in regions such as the Galilee, where there was a majority Jewish population.6 Beyond the use of an Aramaic name and the Aramaic script, the Torah Shrine depicted as the rings central motif gives clear indication of the owners religious affiliation.7 The Torah Shrine, a commonly used symbol in Late Roman and Byzantine synagogues, incarnates the new ritual and spiritual values that became central to Judaism after the destruction of the Temple in Jerusalem in $70 \mathrm{CE}$. Animal sacrifice previously performed by a coterie of priests in the Jerusalem Temple was now replaced by the study of the holy scriptures and the institution of prayer that hitherto could be performed in any-

5 EJ 1971: 1072-1081; 1074: on seals from the 2nd-5th centuries. In Babylonia, from 634 to 644, the caliph forbade Christians and Jews from carrying seals, with exception of exilarchs and geonim.

6 On the methodological difficulties associated with distinguishing Jewish and Christian inscriptions from pagan ones, see Kraemer 1991: 141-162. For the Jewish community in Rome, see Rutgers 1995: 176-184, who points to the overwhelming majority of Greek and Latin inscriptions and the almost complete absence of Semitic inscriptions; for Palestine, see Lapin 1999: 239-268.

7 Incidentally, another Late Antique carnelian seal ring from a clearly Jewish context, supposedly owned by the landlord of a Roman period manor house at Ramat Hanadiv, features neither an Aramaic inscription nor an explicit Jewish symbol. It bears the image of either Poseidon or Apollo (Hirschfeld and Feinberg 2005: 29) and, alternatively, may be an imported Roman seal stone. On Roman seal stones in Jerusalem, see Peleg 2003: $52-67$. 
where, wherever a community was formed and a place of worship was erected.8 Contemporary depictions of Torah Shrines are known from numerous synagogue mosaic floors such as at Hammat Tiberias (Dothan 1983, Pls. 26-27), Beth Alpha (Wilkinson 1978: 16, 20-21), Na'aran, Horvat Susiya, Beth Shean, and Sepphoris (6 ${ }^{\text {th }}$ century, Weiss 2005). Less common is its occurrence in relief sculpture such as in the synagogue at Capernaum (Loffreda 1985: 36). A rare case, given the low chances of preservation is its appearance on a wall painting in the Syrian synagogue at Dura Europos ( $3^{\text {rd }}$ century) .9

Most striking at Zafar is a stepped chamber located below the old cubical mosque (z070) on the south-west foot of the Husn Raydan, known as al-Jahw (Fig. 14-15). Although probably built some 1000 years after the underground cavity (z071), the south-west wall of the mosque aligns itself perfectly with the northern face of the initial descending staircase. This structural coordination may be connected to the fact that an earlier building, possibly contemporary and in fact related to the stepped pool, existed in the same location as the current house of worship. Local sources assume a church to have stood in place of the old mosque, however no concrete evidence can confirm this claim. Conversion of synagogues to churches and vice versa, as recorded in "The Book of the Himyarites" (Moberg 1924: cv, cix), may even suggest that either one or both may have existed in place of the mosque at an earlier time. If numerous tombs uncovered near to the mosque are contemporaneous with the earlier building, it could not have functioned as a synagogue. In contrast, the juxtaposition of tombs with a polytheistic or Christian house of worship would have been possible or even likely. However, given the uncertainty of the site chronology, the function of the earlier building/s, and the relationship between the underground cavity, the building/s on top, and the tombs, the discussion remains speculative.

A more detailed description of the underground structure may help to determine whether additional physical traces of a Jewish presence at Zafar can be detected. After the initial 16 steps, a landing redirects the position of the staircase in a $90^{\circ}$ angle to the left (northward). An additional three steps lead into the pool proper which is of asymmetric form and curves back toward the initial staircase, as if beginning a spiral. The installation is entirely cut from the mafic bedrock. The workmanship is of high quality, typical of the Himyarite period, with smooth walls and precisely cut corners (Yule et al. 2007). The maximum capacity of this underground structure, which was evidently designed to hold water, is 1000 litres. Upon discovery, rainwater filled approximately half of the installation and was recorded at $1.6 \mathrm{~m}$ depth above the floor. At this level the installation held approximately 800 litres. If the water were only $1 \mathrm{~m}$ deep, the volume would have been approximately 500 litres.

There is clearly neither a chronological nor functional connection between the installation and the mosque. Given the pools close structural similarity with Roman-Byzantine miqvaot in Palestine, it can be argued that it originally functioned as a Jewish ritual pool. An astonishing resemblance can be detected if compared, for example, to the numerous ritual pools uncovered at Sepphoris in Galilee (Hoglund and Meyers 1996: 39-43). Though originally believed to have vanished as an installation and practice after the destruction of the Temple

8 Levine (2003: 91-97) points out correctly that the meaning of a certain symbol may vary depending on its context. For a complete and brilliant study on synagogues in Late Antiquity, see also Levine 2005.

9 Levine 1999: 335, fig. 74 (gold glass); 216-217, fig. 31 and 32 (mosaic floors); Goodenough 1953-68, vol. 13: 191-192. But see also Göbl 1973, Siegel-Motivklasse 98a, for an aedicula similar in appearance to the Torah Shrine. 
in Jerusalem (R. Reich 1988: 102-107), miqvaot were recently shown to have maintained their function within the context of at least some Jewish households throughout the Late Roman and even Byzantine periods (Galor in press). While caution is advised when using talmudic sources and mishnaic legal prescriptions as viable historical documents to reconstruct daily life and society in Roman-Byzantine Palestine at large, their value for understanding Jewish ethics and rituals, at least as perceived by the rabbinic elite, is important. From a halakhic (Jewish ritual law) point of view, underground cavity z071 could certainly have functioned as a miqveh. It can hold, even if only partially filled with water, the minimal required quantity of 40 seahs.10 This quantity is necessary to allow full body immersion. Rainwater can easily fill the cavity, though it is not clear if it would have originally been channelled through a pipe or aqueduct or, alternatively, if it would have simply flown directly over the stairs and into the cavity. In the floor of the installation there is no provision for water drainage. Multiple plaster layers were considered an important factor in identifying miqvaot in Palestine, however their indispensable function in all water installations in that region should be stressed. In the regional context of Zafar, no plaster was necessary to render water-holding installations impermeable.
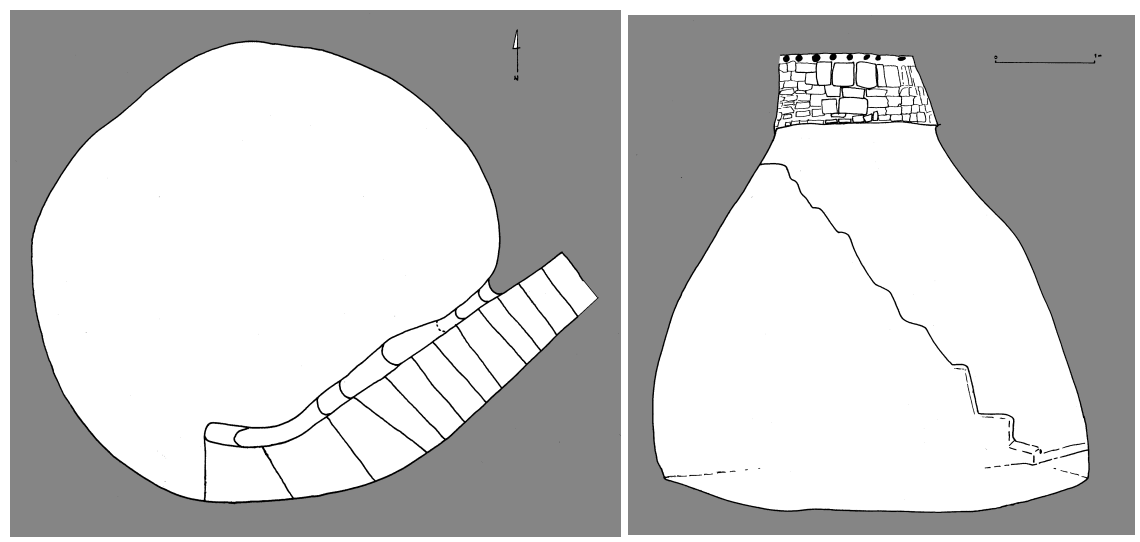

Fig. 17 Plan of the cistern z096.

Fig. 18 Cross section of cistern z096, view to the south-west.

An additional water installation, in this case clearly a cistern (z096, Fig. 16-18), is located $10 \mathrm{~m}$ west of the stepped pool (z071) and measures $4.5 \mathrm{~m}$ in height with a capacity of some 40,000 litres. Although once mentioned as a granary (www.zafar-himyar.com), its identification as a cistern is more likely because rainwater flows into it naturally. If it were a granary, the problem would be to keep the water out. The proximity and similar context of the two water-holding installations invites a comparison. In spite of the difference in tool marks, the high-quality workmanship characteristic of the Himyarite Age suggests that both were built at the same time. The dissimilarity in shape results from their different functions.

In the discussion of early Jewish presence in Himyar, a unique depiction of a male face comes into question owing to the depicted side-lock (Fig. 19, Yule 2005; Doe 1971: 107, pl. 26). With regard to Jewish side-locks in our historical context, three points must first be explained.

First, side-locks (peot in Hebrew) are generally considered a sub-recent eastern European 


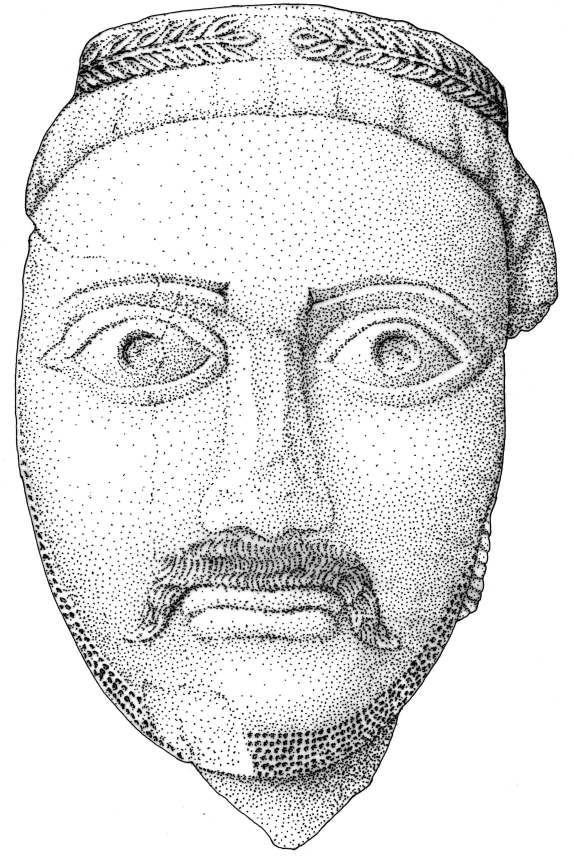

Fig. 19 Himyarite mask in alabaster (calcite), courtesy of Metropolitan Museum of Art, 1982.317.1; Zafar Museum; zm0004; height c. 1.2 m. height $24 \mathrm{~cm}$.

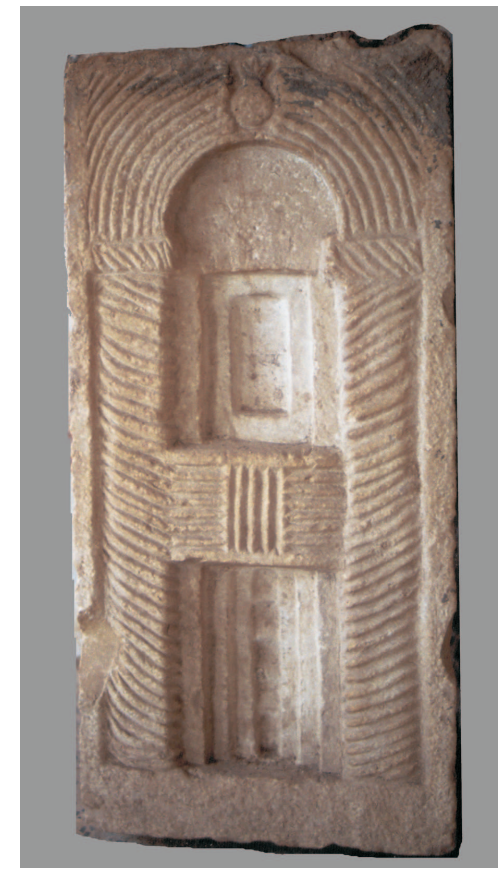

Fig. 20 Niche with a pomegranate and hatched pattern,

practice based on the teachings of the book of Leviticus (19:27). But delving deeper into the matter brings new evidence to light, which is not generally known. First of all, while Goitein concluded that the wearing of peot developed in the Yemen by a decree inveighed against Jewish Sabbatean-messianic activity there in 1667 (Tobi 1995), Lecker (1997) found an earlier reference to a Jew with two side-locks in Pre-Islamic Medina (Yathrib). Secondly, relevant in this context is the dating of the Himyarite mask that shows characteristics datable by means of Roman comparisons to the $2^{\text {nd }}$ or $3^{\text {rd }}$ century CE (similar in style and type: Antonini 2001: Tav. 49, C65). Thirdly, our mask has only a single side-lock and not two, which indicates that this is not an early representation of Jewish side-locks. Nonetheless, the discussion indicates that they existed at least in the late pre-Islamic period, even if representations have not survived.

A well-preserved Himyarite niche fashioned in grey marble, said to have been found in Zafar, may be mentioned as a possible candidate for Jewish iconography (Fig. 20). Above the arch a pomegranate motif is carved. But while the pomegranate is a symbol significant to Jewish art, it also appears in countless other historic Near Eastern contexts. Several niche fragments are included in the collection of the site museum, but this one is intact. Others have also come to light in recent excavations (Yule et al. in press 1), for example, from trench z300. Motifs of similar form have been identified as depictions of a Torah Shrine (Hachlili 1998: 364, Fig. vii-43, depictions on clay lamps). Owing to the small size of the relief, an attribution as a Torah Shrine itself seems unlikely. Thus, other contentual options exist to interpret the origin and meaning of this Himyarite work. To judge from the stylistic details of the stone working, these may date to the $2^{\text {nd }}$ to $4^{\text {th }}$ century CE. The identification as an Islamic mihrab is unlikely owing to the stylistic dating of the stone in the Himyarite age. However, the Sabaean word $m h b$ in this same historical context is translated as a chan- 
cellery, of a king or important personage, for example, but also as an architectural feature (texts: Robin 2006: 160).

Finally, years ago a relief came to light which purportedly came from Baynun in the highlands (Fig. 21 = Radt 1973: Taf. 36.99). The subject of a woman with long locks bearing a bird on her left forearm and a branch in her right handis incised in simple linear fashion into the calcite (alabaster). The extreme linearity of this image is unusual in OSA art (cf. however, another linear relief with the same motif also from Baynun in Radt 1973: Taf. 36.100). Pirennes attribution of the figure as the beneficent goddess Atargatis and its dating to $100 \mathrm{CE}$ are equally unsupported (1977: I. 445-446). This depiction may have adorned a tombstone, but a height of $14.5 \mathrm{~cm}$ for this artefact seems too small for this purpose. The unusual linear style and technique seems more in tune with the $4^{\text {th }}-6^{\text {th }}$ centuries CE than with earlier periods. The branch and bird attributes inevitably bring to mind the dove and olive branch, a standard motif in early Christian art which refers to peace, but also to the holy ghost, and has numerous symbolic attributions. Particularly later, this motif is associated with the first dove Noah sent at the end of the biblical flood that returned with a freshly plucked olive leaf (Gen. 8:10-11). While the dove also plays a role in Jewish iconography as a symbol of peace and given the strong associations with Christian iconography, it seems likely that this is one of the few such examples from the highlands. As understood, it must be one of the earliest uses of this symbol.

\section{Conclusion}

In spite of the difficulty in establishing a precise chronology for the Jewish community in Zafar and the Himyarite region, its presence there in the late pre-Islamic period is widely documented in the literary sources. Archaeologically speaking, the identification of structures, materials, or symbolic attributes that can be associated with specific ethnic and religious affiliations is rather complex a situation not unique to South Arabia. This is true for Late Antiquity as a whole, in particular in regions traversed by international trade routes to facilitate commerce, contact with foreign cultures, and occasionally migration. Exchange and exposure can clearly inspire and enrich a local culture but will, at times, completely disguise its original features and identity. In addition to the geographical considerations of regional movement within and beyond the Himyarite kingdom, we are dealing with other factors which obscure our understanding and recognition of religious identity. The late preIslamic period is one of the most revolutionary phases in the history of religions, during which polytheism was gradually replaced by monotheism, which, in turn, matured and branched into many different streams. Though it is the differences between them that have been a focus of scholarship, it is the commonalities, interconnections, and interdependencies that are far more dominant and significant. The theological and ideological relationships between various religious groups have clear repercussions for the domain of the material remains. Even where one would expect major differences, such as for their houses of worship and burial customs, distinctions are often subtle and more significantly determined by regional-cultural denominators rather than by religious beliefs. In spite of those difficulties to identify the material remains of a specific religious group, some finds at Zafar can almost be certainly classified as "Jewish." 


\title{
Abbreviations
}

\author{
EI Encyclopedia of Islam \\ EJ Encyclopaedia Judaica \\ PSAS Proceedings of the Seminar for Arabian Studies \\ Vienna 1998 Jemen, Kunst und Archäologie im Land der Königin von Saba, Exhibition Catalogue Vienna, \\ Künstlerhaus, 9 November 1998 to 21 February 1999
}

al-Ansary, A.

1981 Qaryat al-Fau, A Portrait of the Pre-Islamic Civilization in Saudi Arabia

Antonini, S.

2001 La statuaria sudarabica in pietra, Repertorio iconografico sudarabico, t. 1

Barceló, M. et al.

2000 Going around Zafar (Yemen). The Banu Ruayn Field Survey: Hydraulic Archaeology and Peasant Work, PSAS 30: 27-39

2003 The Search for the Hararah asdad in the area of Zafár, Governorate Ibb, Yemen, PSAS 33: 133-142

Behnstedt, P.

2002 The Arabic Dialects of al-Yaman. In: EI 11: 277280

Beyer, K.

1984 Die aramäischen Texte vom Toten Meer

Breton, J.-F.

1991 Le château royal de Shabwa: notes d'histoire, Syria 68: 209-227

Doe, D. B.

1971 Southern Arabia

Dothan, M.

1983 Hammath Tiberias: Early Synagogues and the Hellenistic and Roman Remains

EJ

1971 Seal, Seals. In: EJ 14: 1072-1081

Galor, K.

2003 Qumrans Plastered Pools: A New Perspective. In: J.-B. Humbert and J. Gunneweg (eds.), Science and Archaeology at Khirbet Qumran and 'Ain Feshka, Studies in Archaeometry and Anthropology, vol. 2: 169-198

in press The Water Installations of the Sepphoris Acropolis. In: D. Edwards and C. T. McCollough (eds.), The Archaeology of Difference: Gender, Ethnicity and the 'Other in Antiquity, Studies in Honor of Eric M. Meyers

Göbl, R.

1973 Der sasanidische Siegelkanon. Handbuch der mittelasiatischen Numismatik, 4, Braunschweig

Goodenough, E. R.

1953-68 Jewish Symbols in the Greco-Roman Period

Hachlili, R.

1998 Ancient Jewish Art and Archaeology in the Diaspora

Hirschfeld, Y. and Feinberg, M.

2005 A Country Gentlemans Estate. Unearthing the Splendors of Ramat Hanadiv, Biblical Archaeology Review 31/2: 18-31 
Hoglund, K. and Meyers, E.

1996 The Residential Quarter on the Western Summit. In: R. Nagy, C. Meyers, E. Meyers, and Z. Weiss (eds.), Sepphoris in Galilee. Crosscurrents of Culture: $39-43$

Ilan, T.

2002 Lexicon of Jewish Names in Late Antiquity, pt. 1: 103-105

Kraemer, R.

1991 Jewish Tuna and Christian Fish: Identifying Religious Affiliation in Epigraphic Sources, Harvard Theological Review 84: 141-162

Lafitte, R.

2003 Sur le zodiaque sudarabique, Arabia revue de sabéologie 1: 77-87

Lapin, $\mathrm{H}$.

1999 Palestinian Inscriptions and Jewish Ethnicity in Late Antiquity. In: E. M. Meyers (ed.), Galilee through the Centuries. Confluence of Cultures: 239-268

Lecker, M.

1997 Zayd b. Thabit, "A Jew with Two Sidelocks": Judaism and Literacy in Pre-Islamic Medina (Yathrib), Journal of the Near Eastern Society 56: 259-273

Levine, I.

2003 Contextualizing Jewish Art. The Synagogues at Hammat Tiberias and Sepphoris. In: R. Kalmin and S. Schwartz (eds.), Jewish Culture and Society under the Christian Roman Empire: 91131

2005 The Ancient Synagogue. The First Thousand Years. 2nd edition.

Loffreda, S.

1985 Recovering Capharnaum

Moberg, A

1924 The Book of the Himyarites, Fragments of a hitherto Unknown Syriac Work (Skrifter utgivna av Kungl. Humanistiska Vetenskapssamfundet i Lund, VII)

Müller, W.

1979 Zafar und Himjar, Yemen-Report 10: 16-17

Peleg, O.

2003 Roman Intaglio Gemstones from Aelia Capitolina, Palestine Exploration Quarterly 135/1: 52-67.

Pirenne, J. et al.

1977Corpus des inscriptions de antiquités Sud-Arabes

Radt, W.

1973Katalog der staatlichen Antikensammlung von Sanaa und anderer Antiken im Jemen

Rathjens, C./v.Wissmann, H.

1932 Vorislamische Altertümer, Rathjens/v. Wissmansche Südarabien-Reise 2, Abhandlungen aus dem Gebiete der Auslandskunde 38

Reich, R.

1988 The Hot Bath-House (Balneum), the Miqweh and the Jewish Community in the Second Temple Period, Journal of Jewish Studies 39: 102-107

Robin, C.

2003 Le judaïsme de Himyar, Arabia revue de sabéologie 1: 97-172

2006 Himyar juif et chrétien (c. 380-560), Inventaire et analyse des descriptions locales les plus significatives pour les évolutions politiques et religieuses, privately circulated text 
in press Himyar et Israël

Rutgers, L.

1995 The Jews in Late Ancient Rome: Evidence of Cultural Interaction in the Roman Diaspora

Schiettecatte, J.

2004 Une definition de la "ville” préislamique en Arabie du sud, Arabia revue de sabéologie 2: 123-142

Schmidt, J.

1997 Temple und Heiligtümer in Südarabien. Zu den materiallen und formalen Strukturen der Sakralbaukunst, Nürnberger Blätter zur Archäologie 14: 10-40

Sedov, A.

1998 Der Hafen von Qnidas Tor zum Jemen in frühnachchristlicher Zeit. In: Vienna 1998: 274-278

Sima, A.

2002 Die Geschichte der Stadt Zafar (lecture held in Bamberg 29.06.2002)

in press Die Inschriften des Zafar Museums. in: N. Nebes (ed.), Epigraphische Forschungen auf der Arabischen Halbinsel,

Smith, G. R.

2002 Al-Yaman, History from pre-Islamic Times to 1962. In: EI 11: 271-274

Tobi, Y.

1995 Maamaro Shel S.D. Goitein 'al pe'ot we-'al simonim, Têmâ: ketav 'et le heqer yahudût Têmân we tarbûtah, Association for Society and Culture Netanya 32: 97-109

Van Beek, G.W.

1958 Marginally Drafted Pecked Masonry. In: R. LeBaron Bowen and F. P. Albright (eds.), Archaeological Discoveries in South Arabia, II: 287-295

Weiss, Z.

2005 The Sepphoris synagogue: Deciphering an Ancient Message through Its Archaeological and SocioHistorical Contexts

Wilkinson

1978 The Beit Alpha Synagogue Mosaic: Towards an Interpretation. In: Journal of Jewish Art 5: 16-28

Wilkinson, T. J., Edens, C. and Gibson, M.

1997 The Archaeology of the Yemen High Plains: A Preliminary Chronology, Arabian Archaeology and Epigraphy 8: 99-142

Yule, $\mathrm{P}$.

2005 Zafar The Capital of the Ancient Himyarite Empire Rediscovered, Jemen-Report 36: 22-29

2006 Toward a Chronology for Himyarite Sculpture (lecture), Rencontres sabéennes 9, 25-27.05.2005, Jena

2007 Himyar. Spätantike im Jemen/Late Antique Yemen, Aichald

Yule, $\mathrm{P}$.

in press 1 Zafar, Capital of Himyar, Fifth Preliminary Report, February-March 2005, Beiträge zur Archäologie außereuropäischen Kulturen

in press 2 Zafar, Capital of Himyar, Sixth Preliminary Report, February-March 2006, Zeitschrift für Orient-Archäologie, in press 
Yule, P. P. Yule/K. Franke/C. Meyer/G. Nebe/C. Robin/C. Witzel,

2007 Zafar, Capital of Himyar, Ibb Province, Yemen First Preliminary Report: 1998 and 2000, Second Preliminary Report: 2002, Third Preliminary Report: 2003, Fourth Preliminary Report: 2004. In: ABADY 11, 479-547, Pls. $147+$ CD-ROM

P. Yule/K. Franke

in press Zafar, Capital of Himyar, Seventh Preliminary Report, February-March 2007 and February-March 2008, Zeitschrift für Orient Archäologie, in press

Zarins, J. et al.

1983 Preliminary Report on the Najran Ukhdûd Survey and Excavations 1982/1402 AH, Atlal 7: 22-44

Paul Yule

Seminar for the Languages and Cultures of the Near East

Seminar for Prehistory and Near Eastern Archaeology

D-69117 Heidelberg

Tel/Fax 00499515191616

paul.yule@t-online.de

Katharina Galor

Joukowsky Institute for Archaeology and the Ancient World

Brown University

Providence, RI 02912 USA

Katharina_Galor@brown.edu 